\title{
REGIONAL DISPARITIES AND CONVERGENCES IN ASIA
}

\author{
P. Blížkovský1
}

\author{
Received: January 10, 2012
}

\begin{abstract}
BLIŽKOVSKÝ, P.: Regional disparities and convergences in Asia. Acta univ. agric. et silvic. Mendel. Brun., 2012, LX, No. 4, pp. 47-58

This paper analyses the disparity and convergence between the 10 and 11 countries of ASEAN and the Commonwealth of Independent States (CIS) respectively and the 31 sub-national regions (provinces) in China.

The regional disparity levels and trends were analysed using the Gini coefficient between the regions (nominal GDP, GDP per capita and GDP per capita in Purchasing Parity Power, PPP). The convergence analysis was evaluated using the Disparity Range Coefficient (DRC), the Average Disparity Range Coefficient (ADRC), and the $\sigma$ - and $\beta$-convergence. The time period covered was 2000-2008 (ASEAN and CIS) and 2000-2006 (China).

The results show a relatively high regional disparity between the Asian macro-regions of ASEAN and CIS and much lower disparities between the China sub-regions. The disparities were highest if based on the nominal GDP and lower if based on the DGP per capita. The GDP per capita was lower, between 0.30 to 0.4 for the CIS and China, and around 0.7 in ASEAN.

The convergence analysis showed mixed results. Based on the DRC analysis, none of the Asian macroregions converged. All three macro-regions diverged 1.4 to 12.68 times quicker than the average macro-regional GDP per capita grew, ASEAN being at the divergence top and China at the bottom. Based on the ADRC analysis, all macro-regions also proved to diverge. However, the divergence rates were much lower. For macro-regions China and CIS, the divergence was slower than macro-regional growth, thus their divergence was moderate. On the other side, if the macro-region was calculated using the $\sigma$-convergence analysis, the converging macro-regions were ASEAN and China, with 2.13\% and $0.47 \%$ respectively. CIS was diverging at the speed of $1.25 \%$ per year. Based on $\beta$-convergence, ASEAN and China were converging (1.54\% and 1.32\%), and a slow divergence trend was registered for CIS, $1.01 \%$.
\end{abstract}

disparity, convergence, regions, China, ASEAN, Commonwealth of Independent States

\section{INTRODUCTION}

This paper analyses the regional disparities and convergence in selected Asian macro-regions. The regions in the study represent both the macro-regional grouping of countries, such as the Association of Southeast Asian Nations (ASEAN) and the Commonwealth of Independent States (CIS), and a single state (China).
The regional disparities and their evolution represent an important economic and political issue. The homogeneity of the macro-regions is a key parameter for macro-regional cohesion and stability.

The subject is of growing importance also due to the process of globalisation. That is why regional disparities and convergence are a subject of intensive study. In spite of this, the literature offers diverging

1 The opinions expressed in this article are those of the author alone. 
theoretical interpretations concerning te regional convergence (BLİ̌KKOVSKÝ, P., 2011). The neoclassical growth theory (exogenous growth theory, endogenous growth theory (new growth theory), technology gap theory and economic geography theory (new economic geography theory)) suggest regional convergence, regional divergence or a mix of both.

Evidence-based literature is also split - BARRO, J, SALA-I-MARTIN, X. (1992), SALA-I-MARTIN X. (2002, 2006), UNEL, B., ZEBREGS, H. (2006). On the other hand, the OECD (2009) provides no conclusive evidence that the average GDP per capita has converged between OECD regions. Similarly, in the case of Russia, DABLA NORIS, E., WEBER, S. (2001) found that the regional GDP disparities of its 89 regions increased in the time period between 1992 and 1997. This trend is explained by the authors by the dramatic change in economic and policy structures.

The macro-regions adopted various instruments in order to decry regional disparities and stimulate regional convergence.

In the ASEAN macro-region, there is no regional policy at the supranational level as is the case in the EU. The ASEAN countries are however supporting projects which aim to reduce regional disparities. In this chapter, we will present some of the recent projects, based on the Asian Development Bank (2006a, 2006b, 2010a, 2010b, 201la, 2011b), JENNY, H. (2009), MARTINEZ-FERNANDEZ, C., POWELL, M. (2010).

The main projects are co-financed by the Asian Development Bank (ADB). The ADB has since 1995 elaborated the Regional Cooperation and Integration Strategy with 10-20 year roadmaps. Even if the private sector is invited to take part in the projects, the strategy is essentially decided at government level. The strategy focuses on a regional and sub-regional cross-border infrastructure, providing regional public goods, including in the areas of health and the environment.

As regards the CIS, which is a relatively new macro-regional body, its internal development policy is under development. There is no structured regional policy; however, there are several crossborder initiatives. The geographical scope varies and in some cases exceeds the CIS macro-region. The following overview is based on the Asian Development Bank (2000a, 2000b, 2005, 2006, 2009, 2010c, 2010d, 2010e), OECD (2006, 2007), OECD and World Bank (2007), FRANCOIS J., RANA P. B., WIGNARAJA G. (2009a, 2009b) and Central Asia Regional Economic Cooperation and Asian Development Bank (2010).

Concerning China, it is the country with the most rapid growth and change. It is also characterised by high regional disparities. The regional policy of China is active. DYCK, S., LEVINGER, H. (2010) studied the issue more closely. Since the 1970s, with the economic opening and in order to promote economic growth, Specific Economic Zones close to the coastal centres were defined and obtained preferential status in terms of tax and import tariffs. This initiated their spectacular growth but also created disparities vis-à-vis the Western and Central provinces. That is why the central government adopted an active regional 'Go-West' policy, Development of the West. The policy targeted 12 provinces in the West and South. According to the above authors, this strategy is starting to bear fruit as China's growth is starting to be no longer based only on the coastal provinces.

It is worth mentioning the cultural specificity of China, which is translated into regional policy in the concept of building an all-round Xiao Society by 2020 (United Nations Development Programme, 2005). Started in 2002, this longterm vision of reforms was meant principally to alleviate development imbalances in the country. The vision is more a goal than a concrete plan, but it goes together with a range of government reforms and programmes. The definition of Xiao Kang: Xiaokang (in Chinese: 小康) is a Confucian term describing a society of modest means, or a society composed of a functional middle-class. It is loosely equivocated to a "basically well-off" society whereby the people are able to live relatively comfortably, albeit ordinarily. Institutionally, the National Development and Reform Committee has been in charge of the follow-up of the strategy, shifting the party's attention from purely GDP growth towards many issues, including regional wealth disparities and a sustainable agenda. There is even a UNDP programme "Supporting the all-round Xiao Kang Society".

China is involved in various regional initiatives to decrease its regional disparities (OECD, 2002b, OECD, 2008, CHAN, K.W., 2010 and OECD, 2010) as well as for fiscal transfers (HENG, Y. (2008).

\section{METHODOLOGY}

The selection of regions under scrutiny was as follows. In the case of the macro-regions ASEAN and CIS, the regions were represented by 10 and 11 countries respectively. They were compared to the respective macro-region. The reason for this approach is that the sub-national comparable data are not available. In the case of the macroregion China, the regions were represented by 31 provinces. Tab. I provides an overview of the regions analysed.

Concerning the data, the source for ASEAN and CIS was the IMF's World Economic Outlook Database 2009 and namely its online version ${ }^{2}$ that 
I: List of regions within the macro-regions under scrutiny

\begin{tabular}{|c|c|c|}
\hline ASEAN & CIS & China \\
\hline Brunei & Armenia & Beijing \\
\hline Cambodia & Azerbaijan & Tianjin \\
\hline Indonesia & Belarus & Hebei \\
\hline Lao PDR & Kazakhstan & Shanxi \\
\hline Malaysia & Kyrgyz Republic & Inner Mongolia \\
\hline Myanmar & Moldova & Liaoning \\
\hline Philippines & Russia & Jilin \\
\hline Singapore & Tajikistan & Heilongjiang \\
\hline Thailand & Turkmenistan & Shanghai \\
\hline \multirow[t]{22}{*}{ Vietnam } & Ukraine & Jiangsu \\
\hline & Uzbekistan & Zhejiang \\
\hline & & Anhui \\
\hline & & Fujian \\
\hline & & Jiangxi \\
\hline & & Shandong \\
\hline & & Henan \\
\hline & & Hubei \\
\hline & & Hunan \\
\hline & & Guangdong \\
\hline & & Guangxi \\
\hline & & Hainan \\
\hline & & Chongqing \\
\hline & & Sichuan \\
\hline & & Guizhou \\
\hline & & Yunnan \\
\hline & & Tibet \\
\hline & & Shaanxi \\
\hline & & Gansu \\
\hline & & Qinghai \\
\hline & & Ningxia \\
\hline & & Xinjiang \\
\hline
\end{tabular}

allows for self-selection and extraction of data. The statistical departments of the IMF, OECD, WB and UN were contacted and asked to provide the microregional data but all of them replied that they do not possess such data. The micro-regional data was not available from the national statistical offices either. That is why we used only national level data. The data used were the national GDP, GDP per capita and GDP per capita Purchasing Parity Power (PPP) data. The GDP is the nominal GDP expressed in USD in current prices, while the GDP per capita and GDP per capita PPP are expressed in current international USD. The sample period for ASEAN and CIS is 2000-2008. Another methodological comment concerning these two macro-regions is the fact that the macro-regional GDP per capita is not available. That is why it was calculated using the data for the national-level GDP per capita converted to USD. For each year of the sample period the weighting factor was the population of each of the countries - for simplicity, only on the 2008 population data were used.

For China, the micro-regional data of the Chinese National Bureau of Statistics was used. The needed data, namely concerning national accounts, were found dispersed in a series of annual statistical yearbooks. The data used nominal GDP and GDP per capita - both of them are provided in the national currency, CNY. The sample period for the China analysis is 2000-2006. The reason for the shorter period compared to ASEAN and CIS is the non-availability of data for 2007 and 2008. On top of it, the data for 2002 are missing as well due to a technical problem with a corrupted file. The Gini coefficient is not calculated for the GDP per capita in PPP because, in the case of China, there is no microregional data available for GDP per capita in PPP.

To evaluate regional disparities, the Gini coefficient was used. The Gini coefficient was calculated on nominal GDP, GDP per capita and GDP per capita PPP. To analyse the convergence, four methods were used. The Disparity Range Coefficient (DRC) and Average Disparity Range Coefficient (ADRC) combine disparity and convergence measurements. They are built upon a regression analysis. The regression was constructed in such a way as to capture to what extent the distribution of income at the regional level is affected by changes in the macro-regional GDP over a sample period. The DRC is defined, for a particular year, as the difference between the maximum and minimum values of GDP per capita of the micro-regional data for the year in question. The ADRC for a particular year was calculated analogically but, instead of the difference between the maximum and minimum values, it calculates the arithmetic mean of the sum of all distances (in absolute terms) between the GDP per capita of the macro-region and all the values for the corresponding micro-regional GDP per capita for the year. The detailed description of the above methods is described in BLIZKOVSKY, P. (2011). On top of it, the $\sigma$-convergence and $\beta$-convergence were calculated based on the methodology described in detail by ŽIVĚLOVÁ, I., PALÁT, M. (2008) and DUFEK, J., MINAŘÍK, B. (2009).

\section{RESULTS AND DISCUSSION}

\subsection{Results for the macro-region ASEAN}

\subsubsection{Disparity analysis}

Based on the Gini coefficient, the nominal GDP showed (Tab. II) that the level of disparity was high as the Gini coefficient was above 0.50. The trend was towards increasing disparities, with some fluctuations.

The level of regional disparity derived on the basis of GDP per capita (Tab. III) was extremely high, around 0.70, and even higher than in the case of the nominal GDP. The results therefore confirm highly unequal welfare distribution in the ASEAN macro- 
II: Gini coefficient results for GDPfor the macro-region ASEAN

\begin{tabular}{ccccccccc}
\hline \multicolumn{7}{c}{ Gini index (GDP in billions of US Dollars) } \\
\hline $\mathbf{2 0 0 0}$ & $\mathbf{2 0 0 1}$ & $\mathbf{2 0 0 2}$ & $\mathbf{2 0 0 3}$ & $\mathbf{2 0 0 4}$ & $\mathbf{2 0 0 5}$ & $\mathbf{2 0 0 6}$ & $\mathbf{2 0 0 7}$ & $\mathbf{2 0 0 8}$ \\
\hline 0.505318 & 0.507285 & 0.523658 & 0.534122 & 0.530633 & 0.526124 & 0.535954 & 0.532162 & 0.525605 \\
\hline
\end{tabular}

III: Gini coefficient results for the GDP per capita for the macro-region ASEAN

\begin{tabular}{cccccccccc}
\hline \multicolumn{10}{c}{ Gini index (per capita GDP in US Dollars) } \\
\hline $\mathbf{2 0 0 0}$ & $\mathbf{2 0 0 1}$ & $\mathbf{2 0 0 2}$ & $\mathbf{2 0 0 3}$ & $\mathbf{2 0 0 4}$ & $\mathbf{2 0 0 5}$ & $\mathbf{2 0 0 6}$ & $\mathbf{2 0 0 7}$ & $\mathbf{2 0 0 8}$ \\
\hline 0.705899 & 0.700549 & 0.695552 & 0.691676 & 0.696835 & 0.694512 & 0.690003 & 0.686478 & 0.675859 \\
\hline
\end{tabular}

IV: Gini coefficient results for the GDP per capita in PPP for the macro-region ASEAN

\begin{tabular}{ccccccccc}
\hline \multicolumn{7}{c}{ Gini index (per capita GDP in US Dollars PPP) } \\
\hline $\mathbf{2 0 0 0}$ & $\mathbf{2 0 0 1}$ & $\mathbf{2 0 0 2}$ & $\mathbf{2 0 0 3}$ & $\mathbf{2 0 0 4}$ & $\mathbf{2 0 0 5}$ & $\mathbf{2 0 0 6}$ & $\mathbf{2 0 0 7}$ & $\mathbf{2 0 0 8}$ \\
\hline 0.665398 & 0.661948 & 0.659099 & 0.654423 & 0.647482 & 0.639395 & 0.635776 & 0.625278 & 0.619515 \\
\hline
\end{tabular}

region. The trend was very stable, with a marginal closing down of disparities.

Finally, the level of disparity based on individual income in the PPP (Tab. IV) was also very high, around 0.65 . This proves that the regional disparity is substantial even in the case when prices and purchasing parity are reflected.

\subsubsection{Convergence analysis}

The results based on the regression of the DRC manifested a striking divergence trend (Tab. V). The parameter $c_{2}$ equalled 12.6492. This means that, as the macro-regional ASEAN GDP per capita rises, the inequality between the ASEAN member country with the highest GDP per capita and the ASEAN member country with the lowest GDP per capita rises almost 13 times faster than the rate at which macro-regional GDP per capita grows.

The results of ADRC confirm a divergence trend. The speed of divergence was expressed by $c_{2}$, equal to 2.9761. Thus, as the GDP per capita of the macroregion of ASEAN as a whole rises, the average distance between the macro-regional GDP per capita and all 10 ASEAN countries increases 3 times more.

V: Disparity range coefficient (DRC) and Average disparity range coefficient (ADRC), macro-region ASEAN, years 2000-2008

\begin{tabular}{lccc}
\hline & Coefficient & t-statistic & p-value \\
\hline DRC & 12,64915 & 18,76575 & 0,000000 \\
ADRC & 2,976117 & 19,88478 & 0,000000 \\
\hline
\end{tabular}

The result based on the $\sigma$-convergence (Fig. 1) suggests a relatively strong convergence trend among ASEAN, with the annual rate of convergence of $2.13 \%$ and the coefficient of determination high. The result of $\beta$-convergence (Fig. 2) confirms the convergence of an annual speed of $1.54 \%$.

In conclusion the DRC and ADRC results suggest divergence while $\sigma$ and $\beta$-convergence results indicate convergence of its micro-regional output per capita in PPP.

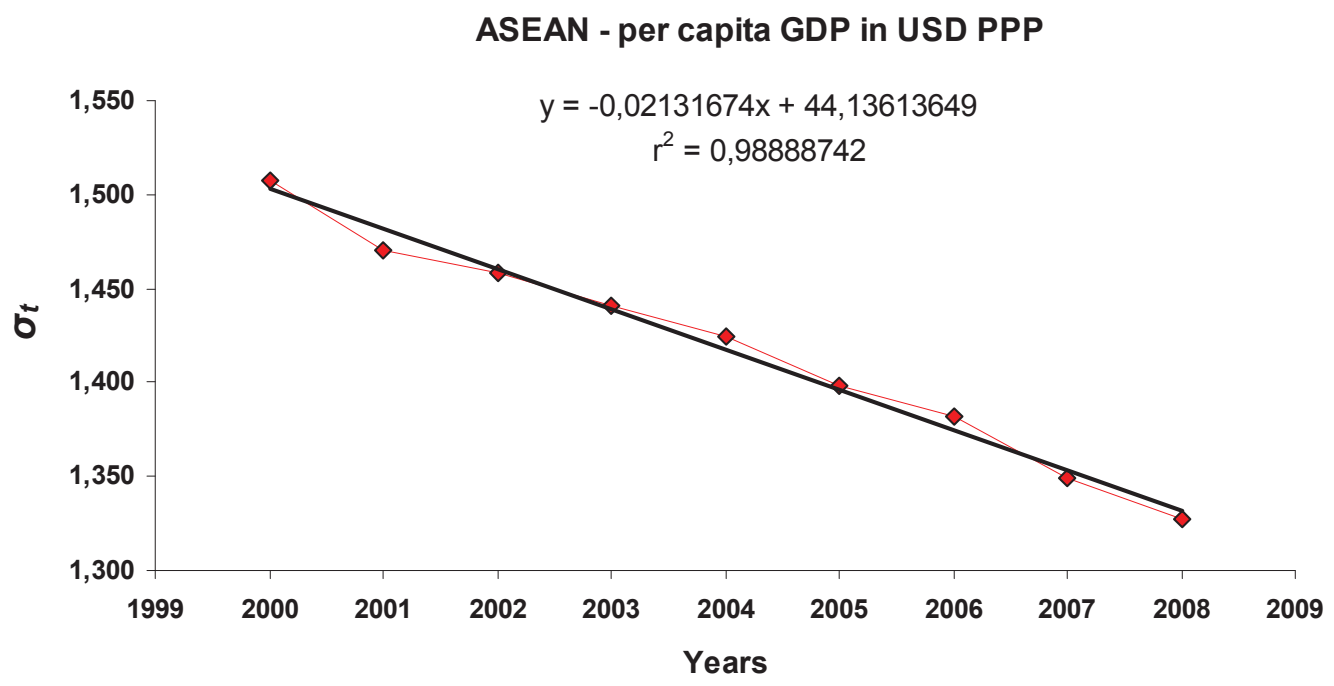

1: The evolution of $\sigma$-convergence for the macro-region ASEAN (GDP per capita in Purchasing Power Parity in USD) 
ASEAN - per capita GDP in USD PPP

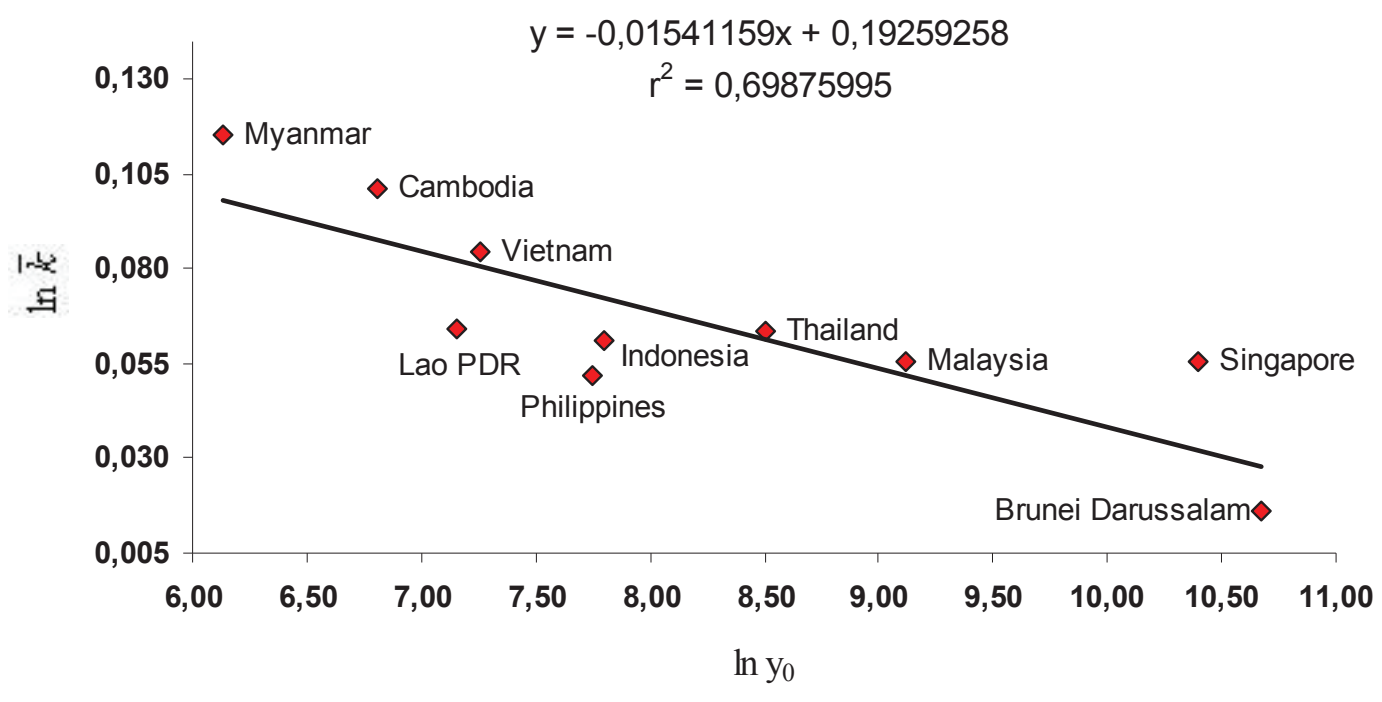

2: The evolution of $\beta$-convergence for the macro-region ASEAN (GDP per capita in Purchasing Power Parity in USD)

\subsection{Results for macro-region CIS}

\subsubsection{Disparity analysis}

Based on nominal GDP, the level of regional disparity was extremely high (Tab. VI) as the Gini coefficient was just below 0.80. The trend was towards increasing the disparities at a slow rate.

As for disparity based on the individual income (Tab. VII), it was much lower and ranged between 0.32 to 0.42 . This exhibits that the inequality based on individual GDP in the CIS countries is at the middle level. The trend however was clearly towards an increase of disparities. The Gini coefficient was rising with a constant trend and in total there is a significant increase of disparity of $25 \%$.

The level of disparity based on individual income in the PPP (Tab. VIII) was once again medium, with a value of around 0.35. It was higher compared to the calculation based on the GDP per capita without weighting by the PPP. This shows that the price adjustment across the CIS countries does not help in decreasing disparities. The trend under this measure was not clear, with very small fluctuations.

\subsubsection{Convergence analysis}

Based on the regression of the DRC (Tab. IX), the results show a divergence trend. The parameter was 1.4085. The disparity between the CIS country with the highest and lowest GDP per capita and the CIS as a whole increased. This regression result based on DRC as the dependent variable is statistically highly significant.

The ADRC analysis results in a slight divergence trend, with a $c_{2}$ value of 0.5698 . It shows that, as the macro-regional GDP per capita rises, the average distance, expressed in GDP per capita, between the macro-regional average and all 11 countries increases as well, though at a lower rate than

VI: Gini coefficient results for the nominal GDP for the macro-region CIS

\begin{tabular}{ccccccccc}
\hline \multicolumn{7}{c}{ Gini index (GDP in billions of US Dollars) } \\
\hline $\mathbf{2 0 0 0}$ & $\mathbf{2 0 0 1}$ & $\mathbf{2 0 0 2}$ & $\mathbf{2 0 0 3}$ & $\mathbf{2 0 0 4}$ & $\mathbf{2 0 0 5}$ & $\mathbf{2 0 0 6}$ & $\mathbf{2 0 0 7}$ & $\mathbf{2 0 0 8}$ \\
\hline 0.777387 & 0.782250 & 0.785491 & 0.789347 & 0.796708 & 0.796872 & 0.796450 & 0.796147 & 0.791757 \\
\hline
\end{tabular}

VII: Gini coefficient results for the GDP per capita for the macro-region CIS

\begin{tabular}{ccccccccc}
\hline \multicolumn{7}{c}{ Gini index (per capita GDP in US Dollars) } \\
\hline $\mathbf{2 0 0 0}$ & $\mathbf{2 0 0 1}$ & $\mathbf{2 0 0 2}$ & $\mathbf{2 0 0 3}$ & $\mathbf{2 0 0 4}$ & $\mathbf{2 0 0 5}$ & $\mathbf{2 0 0 6}$ & $\mathbf{2 0 0 7}$ & $\mathbf{2 0 0 8}$ \\
\hline 0.327352 & 0.356695 & 0.375984 & 0.391114 & 0.405716 & 0.411031 & 0.419465 & 0.411840 & 0.418655 \\
\hline
\end{tabular}

VIII: Gini coefficient results for the GDP per capita in PPP for the macro-region CIS

\begin{tabular}{ccccccccc}
\hline \multicolumn{7}{c}{ Gini index (per capita GDP in US Dollars PPP) } \\
\hline $\mathbf{2 0 0 0}$ & $\mathbf{2 0 0 1}$ & $\mathbf{2 0 0 2}$ & $\mathbf{2 0 0 3}$ & $\mathbf{2 0 0 4}$ & $\mathbf{2 0 0 5}$ & $\mathbf{2 0 0 6}$ & $\mathbf{2 0 0 7}$ & $\mathbf{2 0 0 8}$ \\
\hline 0.355402 & 0.353925 & 0.353644 & 0.351766 & 0.351508 & 0.353118 & 0.353212 & 0.357860 & 0.358086 \\
\hline
\end{tabular}


IX: Disparity range coefficient (DRC) Average disparity range coefficient (ADRC), macro-region CIS, years 2000-2008

\begin{tabular}{lccc}
\hline & Coefficient & t-statistic & p-value \\
\hline DRC & 1.40854 & 290.49310 & 0.00000 \\
ADRC & 0.56980 & 97.32668 & 0.00000 \\
\hline
\end{tabular}

the growth rate of the macro-regional GDP per capita. The regression result is statistically highly significant.

The results of the $\sigma$-convergence (Fig. 3 ) suggest that there is a divergence trend among CIS regions, at an annual rate of the divergence of $1.25 \%$. The $\beta$-convergence (Fig. 4) confirms the findings of the $\sigma$-convergence calculation (divergence of annual speed of $1.01 \%$ ).
In conclusion all four convergence methods suggest that the CIS macro-region is tending towards more divergence of its meso-regional output per capita in PPP.

\subsection{Results for macro-region China}

\subsubsection{Disparity analysis}

The results derived by calculating the Gini coefficient on the basis of nominal GDP (Tab. X) indicate high disparities in terms of the absolute GDP, with a value of 0.42 . The trend was towards a slight increase of the disparity gap.

The level of regional disparity based on individual income was lower (Tab. XI). The Gini coefficient values were between 0.34 and $0.31,20 \%$ lower than for the nominal regional GDP. The inequality based

CIS - per capita GDP in USD PPP

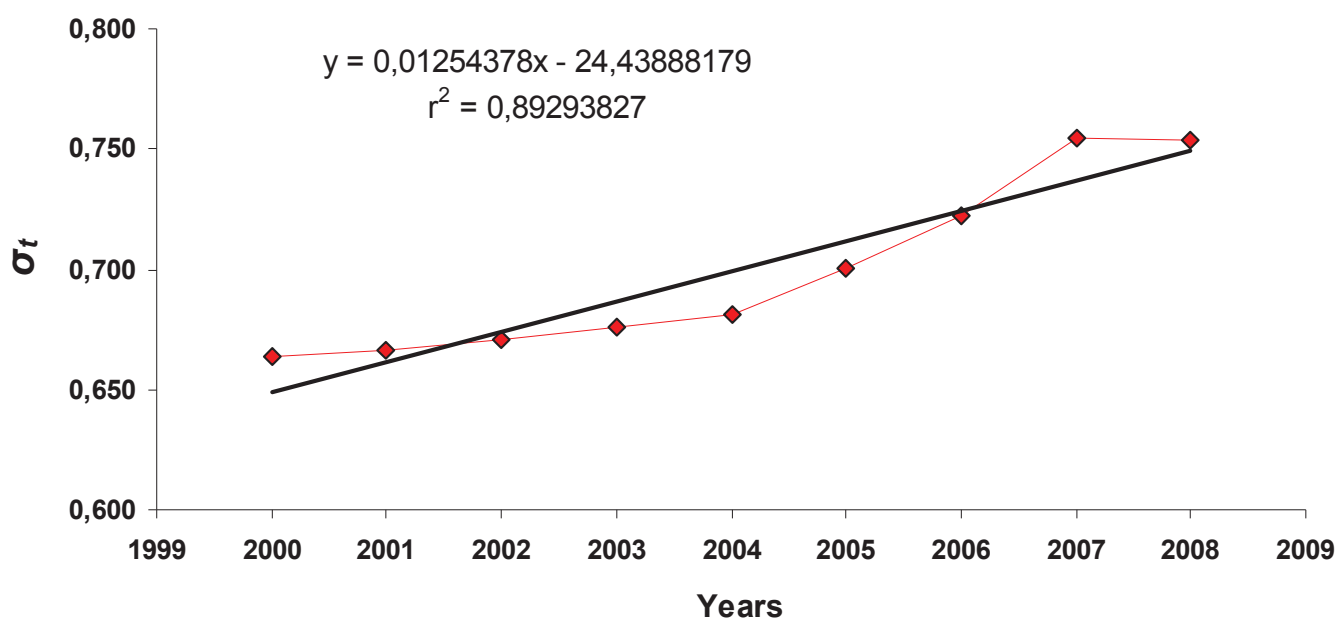

3: The evolution of $\sigma$-convergence for the macro-region CIS (GDP per capita in Purchasing Power Parity in USD)

CIS - per capita GDP in USD PPP

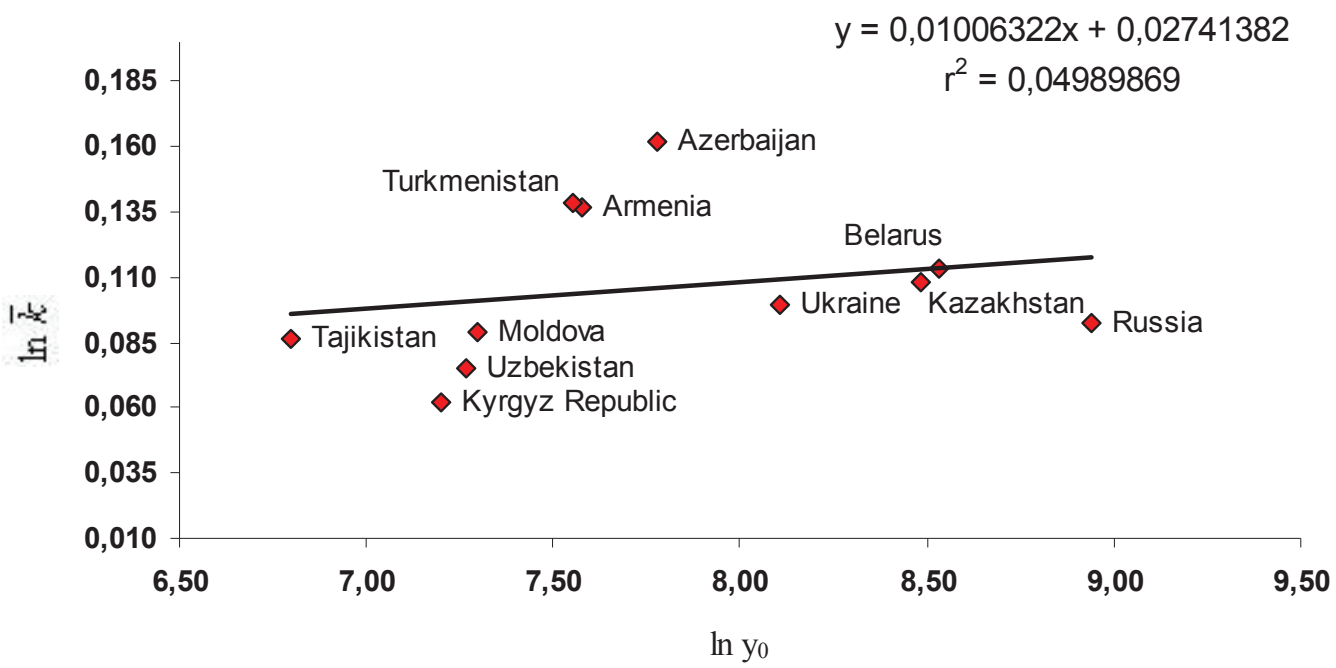

4: The evolution of $\beta$-convergence for the macro-region CIS (GDP per capita in Purchasing Power Parity in USD) 
X: Gini coefficient results for the GDP for the macro-region China

\begin{tabular}{ccccccc}
\hline \multicolumn{7}{c}{ Gini index (GDP in 100 million Yuan) } \\
\hline $\mathbf{2 0 0 0}$ & $\mathbf{2 0 0 1}$ & $\mathbf{2 0 0 2}$ & $\mathbf{2 0 0 3}$ & $\mathbf{2 0 0 4}$ & $\mathbf{2 0 0 5}$ & $\mathbf{2 0 0 6}$ \\
\hline 0.421123 & 0.422222 & 0.421131 & 0.424807 & 0.425678 & 0.431357 & 0.433026 \\
\hline
\end{tabular}

XI: Gini coefficient results for GDP per capita for the macro-region China

\begin{tabular}{cccccccc}
\hline \multicolumn{7}{c}{ Gini index (per capita GDP in Yuan) } \\
\hline $\mathbf{2 0 0 0}$ & $\mathbf{2 0 0 1}$ & $\mathbf{2 0 0 2}$ & $\mathbf{2 0 0 3}$ & $\mathbf{2 0 0 4}$ & $\mathbf{2 0 0 5}$ & $\mathbf{2 0 0 6}$ \\
\hline 0.335845 & 0.337562 & - & 0.341215 & 0.336475 & 0.317567 & 0.312993 \\
\hline
\end{tabular}

on the individual GDP in the China regions is at the medium level. The trend was towards a decreasing of disparities. The Gini coefficient marginally dropped within the time span. There were fluctuations of the disparity levels between the years.

\subsubsection{Convergence analysis}

Based on the regression of the DRC, the results show a divergent trend (Tab. XII). The $c_{2}$ parameter was 2.3709. This attests that, as the GDP per capita of China rises, the disparity between the China microregion with the highest GDP per capita and the China micro-region with the lowest GDP per capita rises 2.37087 times faster. The result is statistically highly significant.

The results based on ADRC present a slight divergence trend. The speed of divergence was below 1 , as the $c$, was 0.4775 . It tells us that, as the macro-regional GDP per capita rises, the average

XII: Disparity range coefficient (DRC) and Average disparity range coefficient (ADRC), macro-region China, years 2000-2006

\begin{tabular}{lccc}
\hline & Coefficient & t-statistic & p-value \\
\hline DRC & 2.37087 & 4.263859 & 0.013 \\
ADRC & 0.47749 & 19.65914 & 0.00 \\
\hline
\end{tabular}

distance, expressed in GDP per capita, between the macro-regional average and all 31 micro-regions increases as well, though at a lower rate than the growth rate of the macro-regional GDP per capita.

The results based on the $\sigma$-convergence (Fig. 5) show a limited convergence trend among China micro-regions with an annual rate $0.47 \%$. The coefficient of determination was just above $50 \%$. The result of $\beta$-convergence (Fig. 6) confirms the convergence trend. The annual speed was $1.3 \%$.

In conclusion the DRC and ADRC results suggest divergence while the $\sigma$ and $\beta$-convergence results indicate convergence of its micro-regional output per capita. Its convergence trend is however statistically not fully conclusive.

By way of discussion, the following can be observed. For the overall results of the convergence analysis, the methods chosen offer different results. Those based on DRC and ADRC tend to be more divergence-oriented. This can be explained by the fact that they focus on the micro-regional gaps rather than on the whole GDP per capita values. Therefore, those methods can be seen as a sort of more detailed tool to evaluate the disparity trend and consequently convergence. The $\sigma$ and $\beta$-convergences are more convergence-sensitive.

\section{China - per capita GDP in USD PPP}

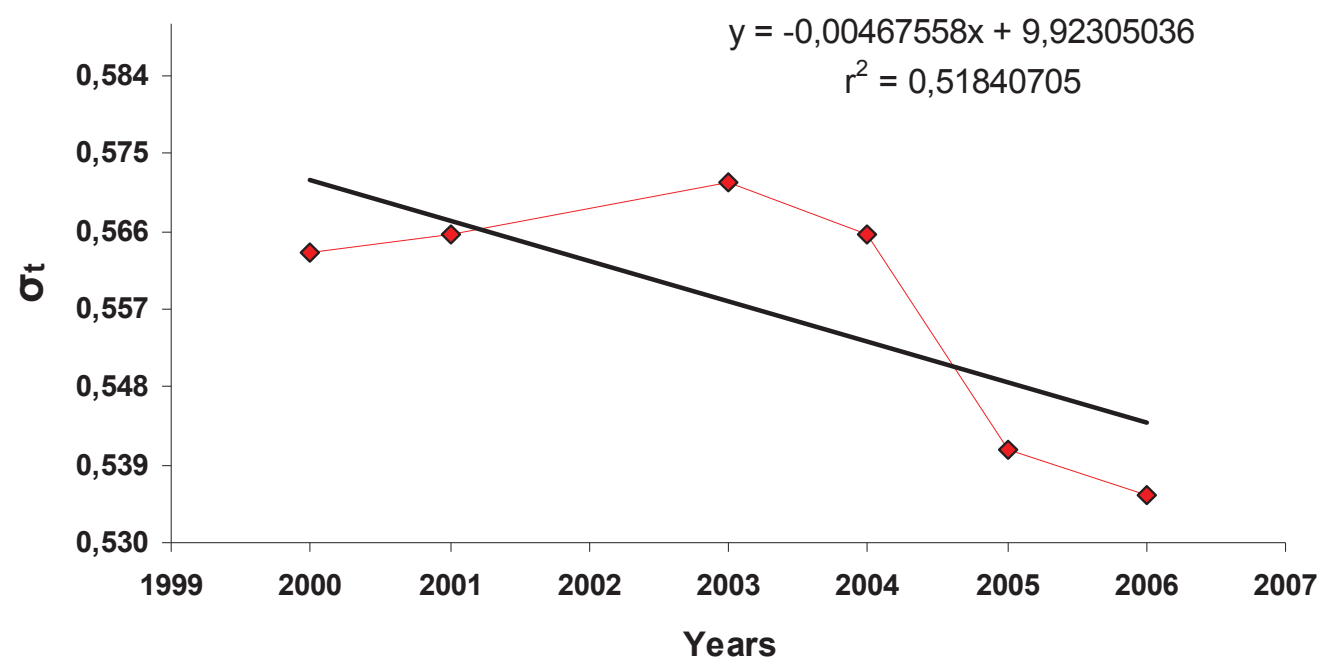

5: The evolution of $\sigma$-convergence for the macro-region China (GDP per capita in USD), years 2000-2006 
CHINA - per capita GDP in USD PPP

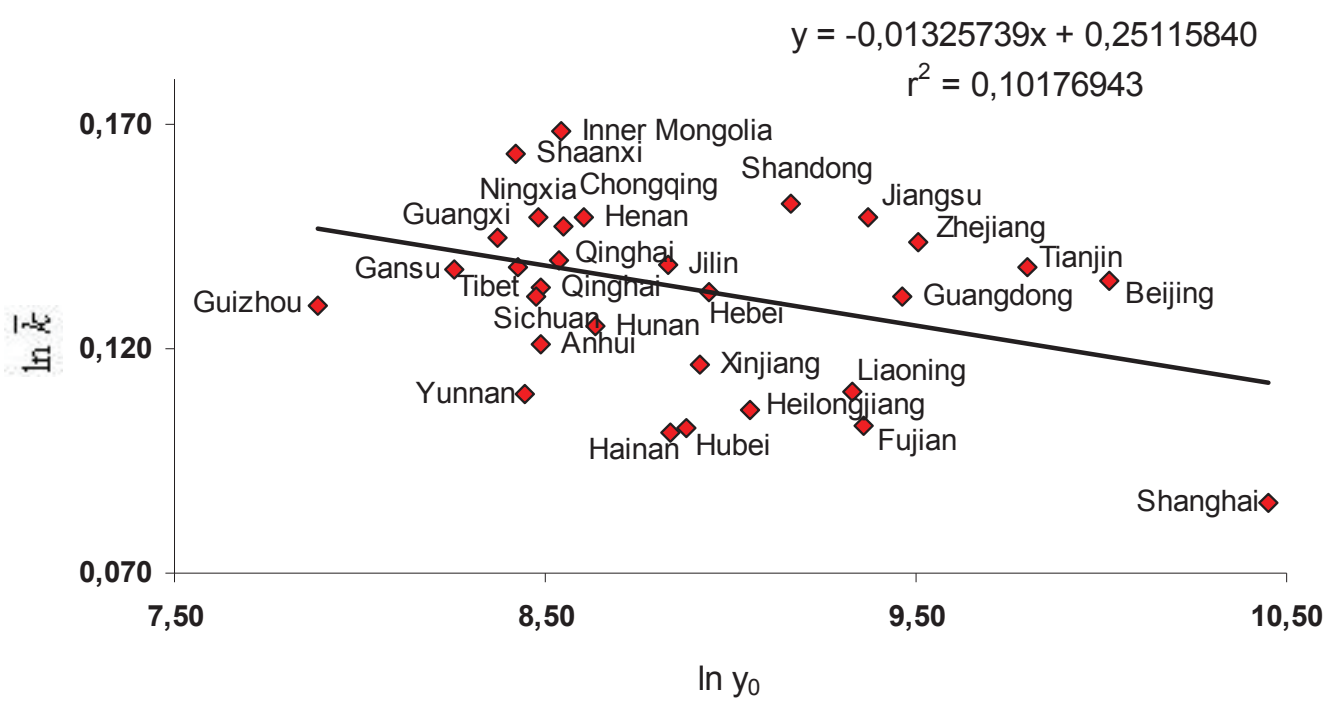

6: The evolution of $\beta$-convergence for the macro-region China (GDP per capita in USD), years 2000-2006

XIII: Convergence or divergence results of the macro-regions based on four methods

\begin{tabular}{lccccc}
\hline Macro-region & $\begin{array}{c}\text { DRC regression } \\
\left(c_{2}\right)\end{array}$ & $\begin{array}{c}\text { ADRC regression } \\
\left(c_{2}\right)\end{array}$ & $\beta$-convergence & $\sigma$-convergence & $\begin{array}{c}\text { Convergence } \\
\text { or divergence }\end{array}$ \\
\hline ASEAN & 12.65 & 2.98 & -1.90 & -1.40 & mixed results \\
CIS & 1.40 & 0.56 & 1.25 & 1.00 & divergence \\
\hline China & 2.37 & 0.48 & -0.47 & -1.32 & mixed results \\
\hline
\end{tabular}

Inside the four methodologies, the two approaches tend to offer similar trends, although the speed of the processes differs. Analysis based on DRC and ADRC detected a divergence trend for all macro-regions. The rate of divergence was however more pronounced in the case of DRC analysis. The $\sigma$ and $\beta$-convergences offer also mutually compatible results with the differentiation of the speeds. Finally, all the convergence results are presented in Tab. XIII.

The dichotomy of results provided by the different methodology confirms the double trend reported in literature. There are various theoretical approaches which suggest either a convergence, a divergence or a mixed trend concerning the convergence of the regions (BLÍŽKOVSKÝ, P., 2011). The $\beta$ - and $\sigma$-convergences correspond to the findings of several studies for various regions (see BARRO, J, SALA-I-MARTIN, X. (1992), and VILLAVERDE, J., SERRA, M. I., PAZIMO, M. F., LINDOW, G., SUTTON, B., RAMIREZ, G., 2006). Divergence and mixed scenarios, based on DRC and ADRC regressions, concord with the outcome of BANERJEE, B., JARMUZEK, M. (2009), BELL, M. W., HOE EE KHOR, OECD (2009) and UNEL, B., ZEBREGS, H. (2006).

The results correspond with the fact that the regional disparities are lower and the convergence trend is stronger in the case of a single-jurisdiction macro-region, such as China. The opposite is true for the macro-regional grouping of countries lacking strong political and economic integration.

Overall, the results suggest a relatively high level of regional disparities plus mixed convergence performance. There are implications for policymaking. According to the selected theoretical starting point and taking into account the real situation of the micro-regions, further research work can be used to define the choice of public policies. It could result in either more active public intervention in the area of regional policy or in the opposite direction. There are issues of governance linked to regional convergence. Disparities and economic convergence (or divergence) are definitely issues for governance at the national level. They can however also play a role in supra-national cooperation and governance in cases of macroregions. This aspect is becoming increasingly important in the current multilateral world.

\section{CONCLUSIONS}

The results for the regional disparity analysis of the selected Asian macro-regions can be summarised as follows:

- Based on nominal GDP, the regional disparities were at relatively high levels in all macro-regions. The lowest disparities were found in China (around 0.4), the mid-level disparity around 0.5 in ASEAN, and the highest one for CIS, with 
the Gini coefficient close to 0.80. The disparity tends towards increasing (ASEAN) or marginal fluctuation (CIS, China).

- Based on GDP per capita, the levels of regional disparity were lower, approximately half or less compared to the nominal GDP measure in CIS and China (0.4 and 0.3 respectively). However, a very high disparity level was confirmed for ASEAN, with the Gini coefficient close to 0.70. Concerning the disparity trends under this measure, both decreasing disparity trends (China) and increasing ones (CIS) were observed. ASEAN showed only marginal fluctuations.

- Based on GDP per capita in PPP, the levels correspond generally to the results for the GDP per capita calculations. A lower regional disparity level, around 0.30, was recorded for the CIS and a high disparity level was confirmed for ASEAN (around 0.65). The disparities dropped in a limited way in ASEAN and stayed stable in CIS.

The convergence analysis results can be summarised as follows:

- Based on the DRC analysis, none of the macroregions converged. There were however differences. All three macro-regions diverged 1.4 to 12.68 times quicker than the average macro- regional GDP per capita grew. The highest regional divergence trend was in ASEAN and the lowest in CIS.

- Based on the ADRC analysis, all macro-regions also proved to diverge. However, the divergence rates were much lower. For macro-regions China and CIS, the divergence was slower than the macro-regional growth, thus their divergence was moderate. On the other hand, the macroregion ASEAN appeared highly diverging with a divergence rate of $2.98 \%$.

- Based on the $\sigma$-convergence analysis, two groups of macro-regions were identified. The converging macro-regions were ASEAN and China. The rate of convergence for China was $0.47 \%$ and for ASEAN 2.13\%. CIS was a diverging macro-region, with a speed of divergence of $1.25 \%$ per year.

- Based on the $\beta$-convergence analysis, ASEAN and China were converging (1.54\% and $1.32 \%$ ) and a slow divergence trend was registered for China, whereas the divergence trend for CIS was at 1.01\%. In summary, the main hypothesis of the study, which foresaw that the Asian macro-regions were converging in terms of their regional GDP per capita, was not confirmed.

\section{SUMMARY}

The results show relatively high disparity levels among the Asian macro-regions. In terms of nominal GDP Gini coefficient the disparities were at high levels in all macro-regions. The lowest disparities were found in China (around 0.4), the mid-level disparity around $0.5 \mathrm{in}$ ASEAN and the highest one for the CIS, with the Gini coefficient close to 0.80. The disparity tends towards increasing (ASEAN) or marginal fluctuation (CIS, China).

Disparity levels based on GDP per capita were lower, approximately half or less compared to the nominal GDP measure in the CIS and China (0.4 and 0.3 respectively). However, a very high level of disparity was confirmed for ASEAN, with the Gini coefficient close to 0.70 . Concerning the disparity trends under this measure, both a decreasing disparity trend (China) and an increasing one (CIS) were observed. ASEAN showed only marginal fluctuations.

Once the GDP per capita in PPP was taken into account, the levels corresponded generally to the results for the GDP per capita calculations. A lower regional disparity level, around 0.30, was recorded for the CIS and a high disparity level was confirmed for ASEAN (around 0.65). The disparities dropped in a limited way in ASEAN and stayed stable in CIS.

The convergence analysis showed mixed results. Based on the DRC analysis, none of the macroregions converged. There were however differences. All three macro-regions diverged 1.4 to 12.68 times more quickly than the average macro-regional GDP per capita grew. The highest regional divergence trend was found in ASEAN and the lowest in CIS.

Based on the ADRC analysis, all macro-regions also proved to diverge. However, the divergence rates were much lower. For macro-regions China and CIS, the divergence was slower than macro-regional growth, thus their divergence was moderate. On the other side, the macro-region ASEAN appeared highly diverging with a divergence rate of $2.98 \%$.

Based on the $\sigma$-convergence analysis, two groups of macro-regions were identified. The converging macro-regions were ASEAN and China. The rate of convergence for China was $0.47 \%$ and for ASEAN $2.13 \%$. CIS was a diverging macro-region, with a speed of divergence of $1.25 \%$ per year.

Finally, based on the $\beta$-convergence analysis, ASEAN and China were converging (1.54\% and $1.32 \%$ ) and a slow divergence trend was registered for China, whereas the divergence trend for CIS was at $1.01 \%$.

In conclusion, the regional disparities were relatively low in China and at high levels in ASEAN and CIS. Regional convergence cannot be confirmed in general, with China and ASEAN proving both 
convergence and divergence trends, depending on the methodology used, and the CIS showing a clear trend of regional divergence.

The study demonstrates the importance of the methodological instrument for the convergence analysis.

\section{REFERENCES}

Asian Development Bank, 2000: Asian Development Outlook 2000, ISBN 0-19-592533-5, Manila.

Asian Development Bank, 2005: Electricity Sectors in CAREC countries, A diagnostic Review of Regulatory Approaches and Challenges, Publication Stock No. 091305, Manila.

Asian Development Bank, 2006a: Regional Cooperation and Integration Strategy, Manila 2006.

Asian Development Bank, 2006b: Increasing Gains from Trade Through Regional Cooperation in Trade Policy, Transport, and Customs Transit, Publication Stock No. 030106, Manila 2006 http:// www.adb.org/Documents/Reports/Pre-HLF-2/ Bishkek-Workshop-Report.pdf.

Asian Development Bank, 2009: Asian Development Outlook 2009: Rebalancing Asia's Growth, ISSN 0117-0481, Manila.

Asian Development Bank, 2010a: Connecting Greater Mekong Sub-region Railways, A strategic Framework, ISBN 978-92-9092-053-3, Mandaluyong City, Philippines 2010.

Asian Development Bank, 2010b: IndonesiaMalaysia-Thailand Growth Triangle (IMT-GT), ADB website, updated 7.12.2010 http://www.adb. org/IMT-GT/about.asp.

Asian Development Bank, 2010c: Development Effectiveness Brief, Armenia, a Historic Country Re-merges, WP No ARM102717, Manila.

Asian Development Bank, 2010d: Development Effectiveness Brief, Armenia, a Historic Country Re-emerges, WP No ARM102717, Manila.

Asian Development Bank, 2010e: Satisfying Hidden Hunger, Addressing Micro-nutriment Deficiencies in Central Asia, ISBN 978-92-9092008-3, Manila 2010.

Asian Development Bank, 201la: BIMP-EAGA - Brunei Darussalam-Indonesia-Malaysia-The Philippines East ASEAN Growth Area, ADB website, updated 30. 03. 2011 http://www.adb.org/ BIMP/about.asp.

Asian Development Bank, 201lb: Greater Mekong Sub-region, ADB website, updated 6. 01. 2011 http://www.adb.org/gms/.

BLİŽKOVSKÝ, P., 2011: Regional Disparities and Convergences in the European Union (in preparation).

BARRO, J., SALA-I-MARTIN, X., 1992: Convergence. The Journal of Political Economy 100 (1992), p 223-251.

Central Asia Regional Economic Cooperation and Asian Development Bank, 2010: CAREC Transport and Trade Facilitation, Partnership for Prosperity. Publication Stock No. ARM174208, Manila 2010,
http://www.adb.org/Documents/reports/CarecTranspo-Trade-Facilitation/CAREC-TranspoTrade-Facilitation.pdf.

DABLA NORIS, E., WEBER, S., 2001: Regional Disparities and Transfer Policies in Russia: Theory and Evidence. International Monetary Fund, WP/01/199.

DUFEK, J., MINAŘÍK, B., 2009: Analýza indikátorů prohodnocenícílů realizace strategie regionálního rozvoje v České republice. Brno, ISBN 978-807375-366-5.

DYCK, S., LEVINGER, H., 2010: China's provinces: Digging one layer deeper, Deutsche Bank Research, February 25, 2010, ISSN Print: 1612314X.

FRANCOIS, J., RANA, P. B., WIGNARAJA, G., 2009a: Pan-Asian Integration: Linking East and South Asia, ISBN 978-0-230-22178-9, Manila.

FRANCOIS, J., RANA, P. B., WIGNARAJA, G., 2009b: National Strategies for Regional Integration: South and East Asian Case Studies, ISBN 9781843317890, Manila.

HENG, Y., 2008: Fiscal disparities and the equalisation effects of fiscal transfers at the county level in China, Annals of Economics and Finance, 9(1), 117-151.

JENNY, H., 2009: Vietnam Urban Development, creating the enabling environment for local economic development, ADB website, January 6th 2009, http://www.adb.org/documents/events/2009/ HPEC-Urban-Infrastructure-Visits/03-HJenny. pdf.

MARTINEZ-FERNANDEZ, C., POWELL, M., 2010: OECD LOCAL ECONOMIC and EMPLOYMENT DEVELOPMENT, Employment and skills Strategies in Southeast Asia, OECD LOCAL ECONOMIC and EMPLOYMENT DEVELOPMENT Working Paper 2010/01 ISSN 2079-4797, Paris.

OECD, 2006: Surface Water Quality Regulation in Moldova: Policy Aspects of the Reform, Working Paper, Paris.

OECD, 2008: Trends in strategies for rural policy The Case of China, 10th Session of the Working Party on Territorial Policy in Rural Areas, Public Governance and Territorial Development Directorate, GOV/TDPC/RUR(2008)2, Paris 2008, ISBN 978-92-64-09225-9.

OECD, 2009: How Regions Grow. Policy Brief. Observer OECD, Paris.

OECD, 2010: OECD Economic Surveys: China, Volume 2010/6 February 2010, Paris.

OECD and World Bank, 2007: Reviews of National Policies for Education: Higher Education in Kazakhstan, ISBN Number: 978-92-64-03316-0, Paris. 
SALA-I-MARTIN, X., 2002: 15 Years of New Growth Economics: What Have We Learnt? Columbia University and Universitat Pompeu Fabra.

SALA-I-MARTIN, X., 2006: The World Distribution of Income: Falling Poverty and Convergence Period. The Quarterly Journal of Economics, Vol. CXXI, Issue 2.

UNEL, B., ZEBREGS, H., 2006: The Dynamics of Provincial Growth in China: A Nonparametric Approach. International Monetary Fund, WP/06/55.
United Nations Development Programme, 2005: Government of the People's Republic of China, Joint Programme, Supporting the "all round" Xiao Kang Society, Programme Document, March 2005, http://www.undp.org.cn/projectdocs/33756.pdf.

ŽIVĚLOVÁ, I., PALÁT, M., 2008: Analýza disparit $v$ kvalité żivota mezi okresy jihomoravského kraje. In: Medzinárodné vedecké dni. Nitra: SPU Nitra, pp. 1451-1460. ISBN 978-80-552-0061-3.

Ing. Petr Blížkovský, Ph.D., Director for Economic and Regional Affairs, General Secretariat of the Council of the European Union, Rue de la Loi 148, 1048 Brussels, Belgium, e-mail: petr.blizkovsky@consilium.europa. 
